Society of London in the awards of the Wollaston Fund in 1953, and the Edmund Johnston Garwood Fund in 1957.

Bradley's active participation as a member of council of a number of geological societies and associations, together with a period (1953-57) as editor of the Yorkshire Geological Society, is a measure of the importance of his contribution to, and interest in, the welfare of his science. His enthusiasm and energy are combined with a strong and pleasant personality and his friends and colleagues look forward with anticipation to a most successful tenure of the chair of geology at the University of Leicester.

Ministry of Supply :

Mr. Lewis Boddington, C.B.E.

Mr. L. Bodpington, a deputy chief scientific officer and director of Royal Naval Aircraft Research and Development at the Ministry of Supply, has been appointed to the rank of chief scientific officer, and will become the director-general of Aircraft Research and Development (R.A.F.) ; he succeeds Air ViceMarshal P. S. Blockey, whose tour of duty with the Ministry of Supply expires in July. Mr. Boddington has been associated with research and development on naval aircraft and aircraft-carrier equipment during the greater part of his career. He joined the Royal Aircraft Establishment in 1936 and became superintendent of the Design Department in 1944. From 1946 until 1951 he was superintendent of the Naval Aircraft Department; he was appointed to Ministry of Supply headquarters in 1951, and later became the director responsible for naval aircraft research and development. $\mathrm{He}_{e}$ has become recognized internationally as the leading authority on naval aeronauties, and his name has been associated with a number of important developments in this field. In particular, the angled deck, of which he was the joint inventor, and the mirror deck-landing sight, which was developed under his direction, have made the operation of aircraft from carriers very much easier and safer, and have been adopted by both the Royal Navy and the United States Navy. $\mathrm{He}$ has also been responsible for the planning and direction of the Royal Aircraft Establishment's new research facilities for naval aircraft at Bedford. In recognition of his services to the development of naval aircraft he was awarded the Bronze Medal of the Royal Aeronautical Society in 1953.

Science Correspondent of the B.B.C.: Mr. C. L. Boltz

THE British Broadcasting Corporation has created a new post at Broadcasting House, that of science correspondent in the News Division. The post is comparable to that of the Division's diplomatic and industrial correspondents and will involve duties on both sound and television. Mr. C. L. Boltz has been appointed to the post. He joined the B.B.C. in 1952, as science correspondent on the European Service, and has been broadcasting to Europe ever since. Educated at Huish's School, Taunton, and at University College, Exeter, Mr. Boltz graduated in mathematies and physics, later taking a degree in psychology at Birkbeck College (University of London) with a view to research. After a period spent in research and teaching (during the War he taught radar at Hackney Technical College), he turned to science writing. Among his best-known books are "Wireless for Beginners" and "A Statue to Mr. Trattles". He has contributed to a number of scientific journals, including Nature and Discovery. He has been an active Fellow of the Physical Society for fifteen years and has served on the Colour Group's committee for two periods. Few people have had so wide an experience of science broadcasting, for during the time he has been broadcasting from Bush House he has covered a vast range of scientific topics. Among European listeners he has a great reputation and he is one of the most popular broadeasters to give talks at Bush House.

\section{International Commission on Higher Education in Nigeria}

IT was announced on April 27 that the Nigerian Government has invited a Commission comprising Nigerian, American, and British members to investigate Nigeria's needs in post-secondary education over the next twenty years, and to recommend to the Nigerian Government what steps should be taken to meet these needs. The cost of this operation is to be met by a grant from the Carnegie Corporation of New York. Sir Eric Ashby, Master of Clare College, Cambridge, has accepted an invitation to be chairman of the Commission. The names of other members of the Commission will be announced when they have all accepted invitations. It is proposed that the full Commission should meet in Nigeria in January and again in August 1960, and should produce a preliminary report for the Nigerian Government by October 1960, when Nigeria attains full independence.

\section{Intelligence Unit for Natural History}

THE formation last year of the Council for Nature (Nature, 181, 867; 1958) has given cohesion to the natural history movement in Great Britain, but there is a fundamental need for a central information service on matters concerned with natural history and nature conservation. At present there is no authoritative source of up-to-date information on these subjects available to naturalists. The B.B.C. has agreed to make an annual grant of $£ 5,000$ for three years to enable the Council for Nature to establish an. Intelligence Unit, the first task of which will be the collection of information on what work is at present being undertaken by individual naturalists and by societies and various other bodies. By the end of the year it should be possible for the Council to provide information and advice, and to foster co-operation schemes of work and intimate what is required in the investigations of neglected fields of work. In particular it is hoped that help and en. couragement can be given to amateur cinematographers wishing to make nature films. These are very important in fostering an interest in wild life in a population which is becoming increasingly urban. The Council for Nature (4l Queen's Gate, London, S.W.7) is grateful to the B.B.C. for its support, which is unconditional and places no restraint on the general services to all.

\section{Space Research in Britain}

Is replying to a question in the House of Commons on April 20, the Minister of Supply, Mr. A. Jones, said that the United Kingdom missile programme could, with some adaptation, give an initial launcher in aid of a space research programme, but of itself could provide neither the satellites nor the instruments needed to attack the scientific problems of space research. The Government was at present considering the question of a British space research project using Earth satellites in the light of advice from the 